\title{
Pengaruh Metode Ekstraksi terhadap Kandungan Senyawa Polifenol dan Aktivitas Antioksidan pada Rubus fraxinifolius
}

\section{(Effect of Extraction Method on Polyphenol Content and Antioxidant Activity of Rubus fraxinifolius)}

\author{
YESI DESMIATY ${ }^{1,2}$, BERNA ELYA ${ }^{1 *}$, FADLINA CHANY SAPUTRI $^{1}$, IIS IRAWATTY DEWI ${ }^{2}$, \\ MUHAMMAD HANAFI ${ }^{2,3}$ \\ ${ }^{1}$ Fakultas Farmasi, Universitas Indonesia, Depok \\ ${ }^{2}$ Fakultas Farmasi, Universitas Pancasila, Jakarta \\ ${ }^{3}$ Pusat Penelitian Kimia Lembaga Ilmu Pengetahuan Indonesia, Serpong \\ *Penulis korespondensi, Hp : 08122044958 \\ e-mail: berna.elya@farmasi.ui.ac.id
}

Diterima 13 Agustus 2019, Disetujui 12 September 2019

\begin{abstract}
Abstrak: Tanaman Rubus fraxinifolius dapat ditemukan di daerah pegunungan Jawa Barat. Penelitian sebelumnya menunjukkan bahwa tanaman ini memiliki aktivitas antioksidan yang sangat kuat. Kandungan senyawa polifenol pada tanaman berkontribusi secara substansial terhadap aktivitas antioksidan dan metode ekstraksi akan mempengaruhi kandungan senyawa yang tersari. Pada penelitian ini dilakukan evaluasi pengaruh metode ekstraksi organ daun, buah muda, dan batang $R$. fraxinifolius terhadap kandungan polifenol serta aktivitas antioksidannya. Bagian daun, buah, dan batang $R$. fraxinifolius diekstraksi cair padat secara maserasi, refluks, dan Soxhlet menggunakan pelarut metanol. Terhadap masing-masing ekstrak dilakukan penetapan kadar polifenol total dengan pereaksi FolinCiocalteu serta uji aktivitas antioksidan dengan metode peredaman DPPH. Rendemen ekstrak terbanyak adalah ekstrak refluks daun $R$. fraxinifolius sebesar 30,20\%. Kandungan polifenol total tertinggi adalah pada ekstrak Soxhlet daun $R$. fraxinifolius sebesar $48,79 \mathrm{mg} \mathrm{GAE} / \mathrm{g}$ ekstrak. Aktivitas antioksidan tertinggi yaitu ekstrak Soxhlet daun $R$. fraxinifolius sebesar 98,29\% pada $100 \mathrm{bpj}$. Dari penelitian ini menunjukan bahwa ekstrak metanol daun $R$. fraxinifolius yang diekstraksi secara Soxhlet memiliki kandungan polifenol serta aktivitas antioksidan tertinggi.
\end{abstract}

Kata kunci: Rubus fraxinifolius, metode ekstraksi, rendemen, polifenolat, antioksidan.

\begin{abstract}
Rubus fraxinifolius can be founded in the mountainous regions of West Java. Previous studies have shown that this plant has potent antioxidant activity. The content of polyphenol compounds in this species contributes substantially to antioxidant activity, and the extraction method will affect the content of the compound. In this study, an evaluation of the extraction method effect on leaves, young fruits, and stems of $R$. fraxinifolius on the content of polyphenols and their antioxidant activity, have been done. The leaves, fruits, and stems of $R$. fraxinifolius were extracted by maceration, reflux, and Soxhlet using methanol as a solvent. Each extract was determined the total polyphenol content using Folin-Ciocalteu reagent and antioxidant activity test using DPPH reduction method. The highest extract yield was $R$. fraxinifolius leaf reflux extract $(30.20 \%)$. The highest total polyphenol content was given by the Soxhlet extract of leaf $R$. fraxinifolius $(48.79 \mathrm{mg} \mathrm{GAE} / \mathrm{g}$ extract). The highest antioxidant activity was leaf Soxhlet extract of $R$. fraxinifolius $(98.29 \%$ at $100 \mathrm{ppm})$. From this study it was shown that the methanol extract of $R$. fraxinifolius leaves extracted by soxhlet gave the highest polyphenol content and antioxidant activity.
\end{abstract}

Keywords: Rubus fraxinifolius, extraction method, extract yield, polyphenol, antioxidant. 


\section{PENDAHULUAN}

GENUS Rubus dari familia rosaceae yang ditemukan terdistribusi luas diseluruh dunia. Ditemukan sekitar 50 spesies di Asia Tenggara dan Australia. Rubus ini umumnya tumbuh pada daratan tinggi dengan

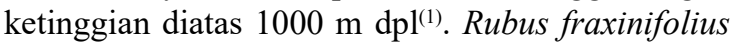
adalah salah satu Rubus yang banyak ditemukan di daerah pengunungan di Indonesia. Di daerah Jawa Barat dikenal dengan nama "arben", buahnya dapat dimakan dan dijual secara komersial. Buahnya mengandung gula yang cukup tinggi, vit $\mathrm{C}$, serta zat besi $^{(2)}$.

Beberapa pustaka menunjukkan bahwa tanaman ini memiliki aktivitas antioksidan kandungan polifenolat serta flavonoid yang tinggi. Secara tradisional, tanaman ini dikenal berkhasiat dalam meredakan morning sickness, anti diare, disentri, memperkuat kehamilan, membantu persalinan, serta digunakan dalam meredakan kram menstruasi ${ }^{(3-6)}$. Organ daun dan batang $R$. fraxinifolius tidak dimanfaatkan oleh masyarakat. Batang arben berduri tajam serta tidak ada informasi penggunaan tradisional dari daun arben sehingga penelitian ini diharapkan dapat meningkatkan pengetahuan dan manfaat lain dari tanaman ini.

Metode ekstraksi yang dilakukan terhadap suatu simplisia akan mempengaruhi kandungan senyawa yang tersari pada ekstrak. Untuk mendapatkan ekstrak yang memiliki aktivitas biologi tertinggi serta dalam pengembangan produk herbal, maka perlu dilakukan observasi metode ekstraksi yang menghasilkan kandungan senyawa aktif terbaik. Metode ekstraksi konvensional yang umum digunakan adalah dengan cara maserasi, refluks, dan Soxhlet. Pada penelitian ini dilakukan ekstraksi dengan 3 cara yaitu maserasi, refluks, dan Soxhlet dengan parameter rendemen, kadar polifenolat, serta aktivitas antioksidan terhadap organ daun, buah, dan batang $R$. fraxinifolius.

\section{BAHAN DAN METODE}

BAHAN. Daun, batang, dan buah muda $R$. fraxinifolius, metanol teknis (Brataco), pereaksi Folin-Ciocalteu (Sigma), natrium karbonat, asam galat (Sigma), DPPH (Sigma).

METODE. Penyiapan Simplisia dan Ekstrak. Daun, batang, dan buah muda $R$. fraxinifolius diperoleh dari daerah Cibodas, Jawa Barat, dideterminasi di Lembaga Biologi, LIPI, Cibinong. Semua bahan dibersihkan, dikering anginkan hingga diperoleh simplisia kering dan dihaluskan hingga derajat halus 4/18. Terhadap sejumlah 50 gram serbuk simplisia, masing-masing dilakukan ekstraksi cair padat yaitu maserasi ( $250 \mathrm{~mL}$ x 3), Soxhlet $(750 \mathrm{~mL})$, dan refluks (250 mL x 3) menggunakan metanol sebagai pelarut. Masing-masing ekstrak diuapkan pada rotavapor dan dikeringkan di atas tangas air.

Penetapan Kadar Polifenolat Total. Pengujian dilakukan menggunakan metode microplate modifikasi dengan pereaksi Folin-Ciocalteu ${ }^{(7)}$. Sejumlah $20 \mu \mathrm{L}$ masing-masing ekstrak dalam metanol dicampur dengan larutan Folin-Ciocalteu (Sigma) (1:4 dalam air suling) dalam sumuran 96-nunc microplate, kemudian ditambahkan $80 \mu \mathrm{L}$ natrium karbonat (100 g/L). Campuran diinkubasi selama 2 jam dan serapan diukur pada $750 \mathrm{~nm}$ menggunakan Versamac microplate spectrophotometer. Kadar akhir ekstrak dalam sumuran adalah 100 bpj. Selanjutnya serapan ekstrak di plot pada kurva kalibrasi asam galat sebagai larutan standar sehingga diperoleh angka kesetaraan asam galat dalam mg GAE/g ekstrak.

Uji aktivitas antioksidan. Penentuan aktivitas antioksidan didasarkan pada kemampuan ekstrak dalam meredam radikal bebas DPPH menggunakan metode microplate yang dimodifikasi ${ }^{(7)}$. Sejumlah $180 \mu \mathrm{L}$ larutan DPPH dalam metanol (6 mg/100 $\mathrm{mL}$ ) dicampur dengan $20 \mu \mathrm{L}$ ekstrak pada sumuran 96-nunc microplate sehingga diperoleh kadar akhir ekstrak 100 bpj per sumuran. Campuran dikocok dan diinkubasi pada suhu kamar terlindung cahaya selama 30 menit. Pengukuran serapan ekstrak dilakukan menggunakan alat microplate reader (Versamac) pada panjang gelombang $516 \mathrm{~nm}$ dengan larutan kontrol adalah larutan DPPH dalam metanol. Dihitung persen peredaman radikal bebas DPPH masing-masing secara triplo.

\section{HASIL DAN PEMBAHASAN}

Ekstraksi Cair Padat (ECP) adalah suatu fenomena perpindahan massa, yaitu zat terkandung dalam matriks padat bermigrasi ke pelarut yang kontak dengan matriks. Fenomena transportasi massa ini dapat ditingkatkan dengan perubahan gradien konsentrasi, koefisien difusi, atau merusak membran sel. Efisiensi ekstraksi dipengaruhi oleh kondisi proses.

Beberapa faktor akan mempengaruhi konsentrasi komponen yang diinginkan dalam ekstrak seperti suhu, rasio cairan-padat, laju alir, dan ukuran partikel. Misalnya, kandungan polifenolat ekstrak almon ditemukan tiga kali lebih tinggi bila proses ECP dilakukan pada suhu $50{ }^{\circ} \mathrm{C}$ jika dibandingkan ekstraksi pada suhu $25^{\circ} \mathrm{C}$. Waktu kontak dan rasio cairan-padat juga menjadi variabel yang signifikan. Metode ekstraksi beberapa senyawa polifenolat 
lebih efektif menggunakan metanol atau etanol asam sebagai pengekstraksi ${ }^{(8)}$.

Dari hasil ekstraksi, dapat terlihat bahwa rendemen tertinggi adalah daun $R$. fraxinifolius yang diperoleh dengan cara refluks (Gambar 1). Hal ini menunjukkan bahwa metode panas dapat menyari senyawa yang terkandung dalam simplisia. Metode refluks merupakan metode ekstraksi yang sederhana, murah, dan mudah di upscale pada skala industri.

Senyawa polifenolat merupakan kelompok senyawa metabolit sekunder terbesar dalam tanaman, memiliki struktur yang berbeda-beda mengandung satu atau lebih cincin aromatik dengan satu atau lebih gugus hidroksil menyertainya. Beberapa penelitian menunjukkan senyawa polifenolat memiliki aktivitas kuat dalam menghambat aktivitas enzim dan $\operatorname{antioksidan}^{(9,10)}$.

Telah diuji secara eksperimental bahwa polifenolat tidak hanya mencegah berbagai penyakit tetapi juga berdampak pada penekanan perkembangan penyakit dan bahkan berkontribusi pada proses penyembuhan. Oleh karena itu, polifenolat saat ini mewakili target utama penelitian antioksidan dan antikanker. Pereaksi Folin Ciocalteu (FCR) merupakan pereaksi yang umum digunakan pada pengukuran kadar senyawa polifenolat pada ekstrak ${ }^{(11)}$. FCR merupakan campuran fosfotungstat dan fosfomolibdat yang akan mengoksidasi senyawa polifenolat menjadi senyawa kompleks berwarna biru sehingga dapat diukur secara kolorimetri $^{(12)}$.

Dari hasil penelitian (Gambar 2) menunjukkan bahwa kandungan polifenolat tertinggi diperoleh dari daun dengan metode ekstraksi menggunakan Soxhlet. Sementara bagian buah $R$. fraxinifolius mengandung lebih sedikit polifenolat, hal ini sesuai dengan beberapa penelitian lainnya ${ }^{(3,10)}$. Kandungan polifenolat dari buah $R$. fraxinifolius terutama dari golongan antosianin, elagitanin, serta proantosianidin ${ }^{(10)}$.

Salah satu metode yang dapat menggambarkan aktivitas antioksidan pada suatu simplisia, ekstrak atau sumber biologis lainnya adalah dengan metode peredaman radikal bebas DPPH $(\alpha, \alpha$-diphenyl- $\beta$ picrylhydrazyl). Metode ini dikembangkan oleh Blois (1958) yang didasarkan pada reaksi reduksi

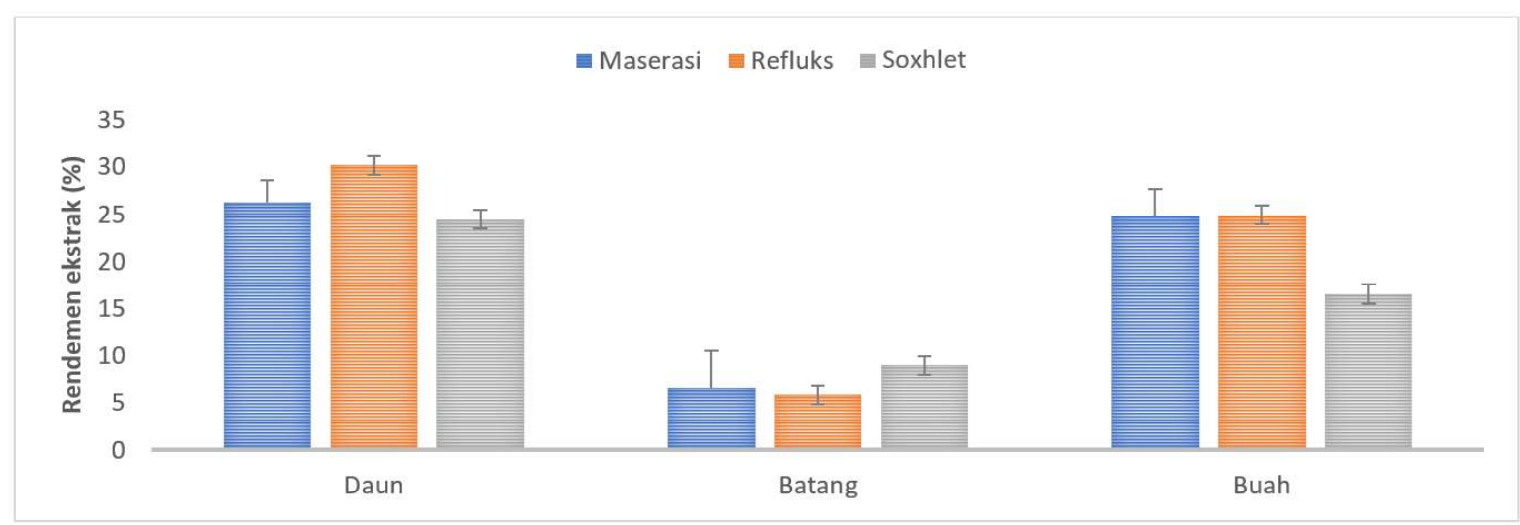

Gambar 1. Hasil rendemen ekstrak $R$. fraxinifolius dengan beberapa metode ekstraksi (n=2).

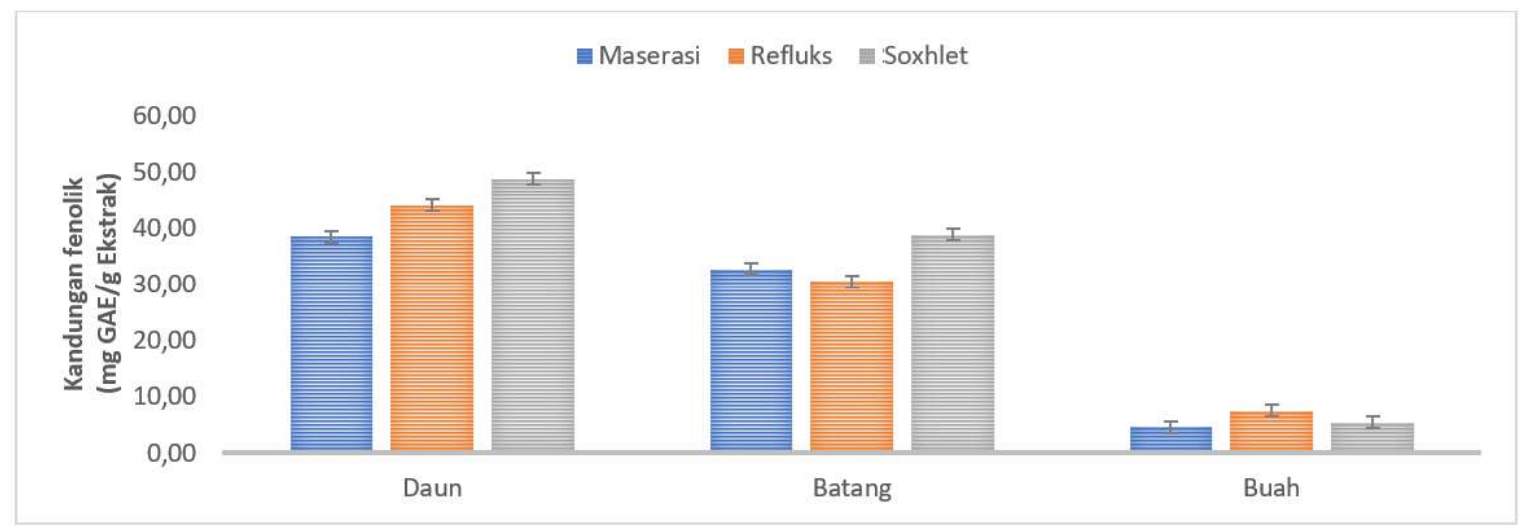

Gambar 2. Hasil kandungan total polifenolat ekstrak $R$. fraxinifolius $(\mathrm{n}=3)$. 


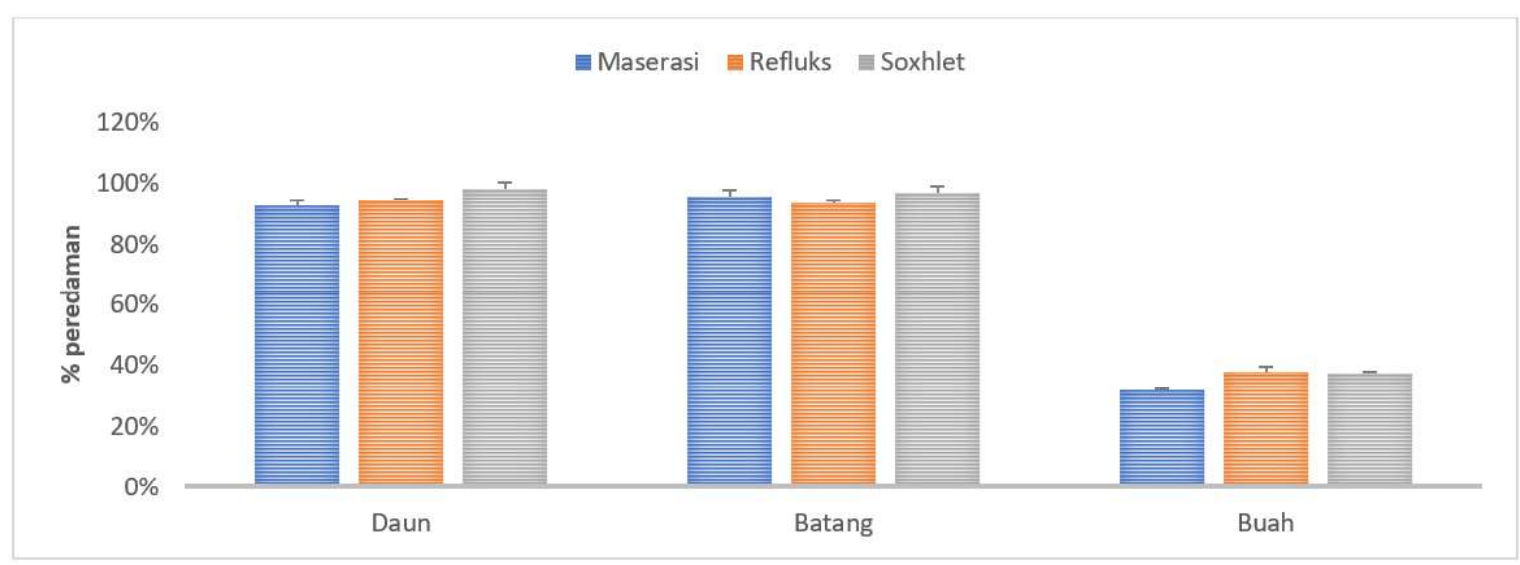

Gambar 3. Hasil uji aktivitas antioksidan ekstrak $R$. fraxinifolius $(\mathrm{n}=3)$.

elektron tak berpasangan pada atom nitrogen oleh atom hidrogen dari antioksidan dan membentuk gugus hidrazin yang berwarna kuning. Pada metode ini dapat diukur perubahan serapan DPPH yang belum bereaksi dengan sisa DPPH yang telah bereaksi dengan antioksidan. Uji antoksidan menggunakan DPPH ini merupakan metode yang valid, akurat, reprodusibel, mudah, serta murah. Salah satu kelemahan metode ini adalah kurang baik bila bahan uji berupa emulsi atau plasma, karena protein yang terdapat dalam plasma akan mengendap ${ }^{(13)}$.

Pada penelitian ini menunjukkan bahwa daun dan batang $R$. fraxinifolius memiliki kemampuan sebagai antioksidan yang sangat kuat (Gambar 3). Hal ini sesuai dengan hasil penelitian lainnya yang menunjukkan bahwa daun $R$. fraxinifolius memiliki aktivitas antioksidan yang kuat sementara buahnya memiliki aktivitas yang lebih lemah ${ }^{(3,5,6)}$. Ekstraksi menggunakan cara Soxhlet dapat menyari lebih banyak senyawa yang bersifat antioksidan.

Dari analisis korelasi Pearson, diperoleh hasil koefisien korelasi (r) antara aktivitas antioksidan dengan kandungan polifenolat sebesar 0,9578. Menurut kriteria Guillford, angka koefisien korelasi (r) $>0,9$ menunjukkan adanya hubungan yang sangat kuat. Hal ini sesuai dengan penelitian lain yang juga menunjukkan bahwa aktivitas antioksidan diberikan oleh senyawa-senyawa yang memiliki gugus polifenolat ${ }^{(14,15)}$

\section{SIMPULAN}

Pada penelitian ini didapatkan hasil bahwa metode refluks pada ekstraksi $R$. fraxinifolius memberikan hasil rendemen lebih banyak, tetapi metode Soxhlet dapat menyari senyawa polifenolat dan senyawa antioksidan lebih banyak. Organ daun $R$. fraxinifolius memiliki senyawa polifenolat dan senyawa antioksidan lebih banyak dibadingkan organ lainnya. Penelitian ini bermanfaat sebagai acuan pada penelitian $R$. fraxinifolius selanjutnya.

\section{DAFTAR PUSTAKA}

1. Kalkman C, Verheij EWM, Coronel R. Rubus [Internet]. PROSEA (Plant Resources of South-East Asia) Foundation. 1991 [cited 2019 Sept 8]. Available from: http://proseanet.org

2. Surya MI, Suhartati S, Ismaini L, Lusini Y, Destri D, Anggraeni D, et al. Fruit Nutrients of Five Species of Wild Raspberries (Rubus spp.) from Indonesian Mountain's Forests. J Trop Life Sci. 2018;Jan 15;8(1):75-80.

3. Bakar MFA, Ismail NA, Isha A, Ling ALM. Phytochemical Composition and Biological Activities of Selected Wild Berries (Rubus moluccanus L., R. fraxinifolius Poir., and $R$. alpestris Blume). EvidenceBased Complement Altern Med. 2016. 1-10.

4. Shamsudin NA, Matawali A, Azlan J. Comparison of Antioxidant Activity and Phytochemical Content of Borneo Wild Berry, Rubus fraxinifolius (Rogimot). Vol. 6, Transactions on Science and Technology. 2019.

5. Galvez MAC. Evaluation of DPPH Free Radical Scavenging Activity and Phytochemical Screening of Selected Folkloric Medicinal Plants in Tinoc, Ifugao, Cordillera Administrative Region, Philippines. Int J Sci Res Publ. 2014;5(12).

6. Desmiaty Y, Elya B, Saputri FC, Hanafi M, Prastiwi R. Antioxidant Activity of Rubus fraxinifolius Poir. and Rubus rosifolius J. Sm. Leaves. J Young Pharm. 2018;10(2s):S93-6.

7. Bobo-García G, Davidov-Pardo G, Arroqui C, Vírseda P, Marín-Arroyo MR, Navarro M. Intralaboratory validation of microplate methods for total phenolic content and antioxidant activity 
on polyphenolic extracts, and comparison with conventional spectrophotometric methods. J Sci Food Agric. 2015;95(1):204-9.

8. Ignat I, Volf I, Popa VI. A critical review of methods for characterisation of polyphenolic compounds in fruits and vegetables. Food Chem. 2011;126(4):1821-35.

9. Karim AA, Azlan A, Ismail A, Hashim P, Abd Gani SS, Zainudin BH, et al. Phenolic composition, antioxidant, anti-wrinkles and tyrosinase inhibitory activities of cocoa pod extract. BMC Complement Altern Med. 2014;14(1):381.

10. Barcelo R. Phytochemical Screening and Antioxidant Activity of Edible Wild Fruits in Benguet, Cordillera Administrative Region, Philippines. Electron J Biol. 2015;11(3):80-9.

11. Mojzer EB, SKerget M, Knez Z, Bren U. Polyphenols: Extraction methods, antioxidative action, bioavailability and anticarcinogenic effects. Molecules. 2016;21(7).
12. Pientaweeratch S, Panapisal V, Tansirikongkol A. Antioxidant, anti-collagenase and anti-elastase activities of Phyllanthus emblica, Manilkara zapota and silymarin: an in vitro comparative study for antiaging applications. Pharm Biol. 2016;54(9):1865-72.

13. Kedare SB, Singh RP. Genesis and development of DPPH method of antioxidant assay. J Food Sci Technol. 2011;48(4):412-22.

14. Fu L, Xu BT, Xu XR, Qin XS, Gan RY, Li H Bin. Antioxidant capacities and total phenolic contents of 56 wild fruits from South China. Molecules. 2010;15(12):8602-17.

15. Poulin RC, Sasikumar JM, Meseret CE, Selvakumar P. In vitro analysis of antioxidant capacity of Indian yellow raspberry (Rubus ellipticus Smith.). International Food Research Journal. 2015; 22(4): 1338-1346 